\title{
PENGARUH RASIO KEUANGAN TERHADAP PERTUMBUHAN LABA PADA PERUSAHAAN SEKTOR PEMBIAYAAN YANG TERDAFTAR DI BEI TAHUN 2014-2018
}

\author{
Ayu Lestari ${ }^{1}$, Pudyartono ${ }^{2}$, Fatichatur Rachmaniyah ${ }^{3}$ \\ Ayulestari007.al@gmail.com \\ Pudy64@yahoo.com \\ Fatichaturrachmaniyah@unisda.ac.id \\ ${ }^{1}$ Mahasiswa Jurusan Akuntansi Universitas Islam Darul 'Ulum Lamongan
${ }^{2,3}$ Dosen Jurusan Akuntansi Universitas Islam Darul 'Ulum Lamongan
}

\begin{abstract}
Profit growth is one indicator that is used to measure the achievement of the company in a period. Profit growth can be predicted through financial ratios analysis. This study aims to determine the effect of financial ratios on profit growth in finance sector companies listed on the IDX in 2014-2018. This study uses a quantitative approach. The sampling technique is through a purposive sampling method with a population of the total number of finance sector companies listed on the IDX in 2014-2018. While the data analysis technique uses multiple linear regression analysis. The results showed that a partial current ratio, debt to asset ratio, and return on asset had a positive and significant impact on profit growth. Return on equity affects negative and not significant to profit growth. Simultaneously, the financial ratios (current ratio, debt to asset ratio, return on asset, and return on equity) have a significant effect on the growth.
\end{abstract}

Keywords: Current Ratio, Debt To Asset Ratio, Return On Asset, Return On Equity, Profit Growth

\begin{abstract}
ABSTRAK
Pertumbuhan laba merupakan salah satu indikator yang digunakan untuk mengukur pencapaian perusahaan dalam suatu periode. Pertumbuhan laba dapat diprediksi melalui analisis rasio keuangan. Penelitian ini bertujuan untuk mengetahui pengaruh rasio keuangan terhadap pertumbuhan laba pada perusahaan sektor pembiayaan yang terdaftar di BEI tahun 2014-2018. Penelitian ini menggunakan pendekatan kuantitatif. Teknik pengambilan sampel melalui metode purposive sampling dengan populasi jumlah keseluruhan perusahaan sektor pembiayaan yang terdaftar di BEI Tahun 2014-2018. Sedangkan teknik analisis data menggunakan analisis regresi linear berganda. Hasil penelitian menunjukkan bahwa secara parsial current ratio, debt to asset ratio, dan return on asset berpengaruh positif dan signifikan terhadap pertumbuhan laba. Sedangkan return on equity berpengaruh negatif dan tidak signifikan terhadap pertumbuhan laba. Secara simultan, rasio keuangan (current ratio, debt to asset ratio, return on asset, dan return on equity) berpengaruh signifikan terhadap pertumbuhan laba.
\end{abstract}

Kata Kunci: Current Ratio, Debt To Asset Ratio, Return On Asset, Return On Equity, Pertumbuhan Laba 


\section{PENDAHULUAN}

Perusahaan pembiayaan, merupakan badan usaha yang khusus didirikan untuk melakukan sewa guna usaha, anjak piutang, pembiayaan konsumen, dan/atau kartu kredit (Yansi dan Tetuko, 2015). Sedangkan menurut Otoritas Jasa Keuangan (OJK) lembaga pembiayaan dapat diartikan sebagai badan usaha yang melakukan kegiatan pembiayaan dalam bentuk penyediaan dana atau barang modal. Kegiatan utama perusahaan pembiayaan adalah menyediakan dana bagi konsumen guna membeli barang maupun modal usaha, dimana dalam proses pengembalian atau pembayarannya dilakukan secara kredit/mengangsur. Fasilitas yang disediakan perusahaan pembiayaan ini cukup meringankan beban konsumen yang kekurangan dana dalam membeli barang yang dibutuhkan untuk mendukung kegiatan usahanya. Oleh karena itu perusahaan pembiayaan berperan penting sebagai alternatif pembiayaan dalam menunjang pertumbuhan dan perkembangan ekonomi nasional.

Menurut OJK pada tahun 2018, dari 193 perusahaan pembiayaan yang terdaftar, sekitar $88 \%$ masuk kategori sehat dan 12\% dikategorikan tidak sehat. Bahkan hingga tahun 2019 bisnis perusahaan pembiayaan masih belum sesuai ekspektasi. Data OJK mencatat hingga Juni 2019 kinerja perusahaan pembiayaan hanya tumbuh 4, 29\%. Nilai ini tumbuh tahun ke tahun dari posisi Juni 2018 (Walfajri, 2019). Hal ini terjadi karena ketidaktepatan para multifinance tersebut dalam menjalankan proses dan target bisnis.

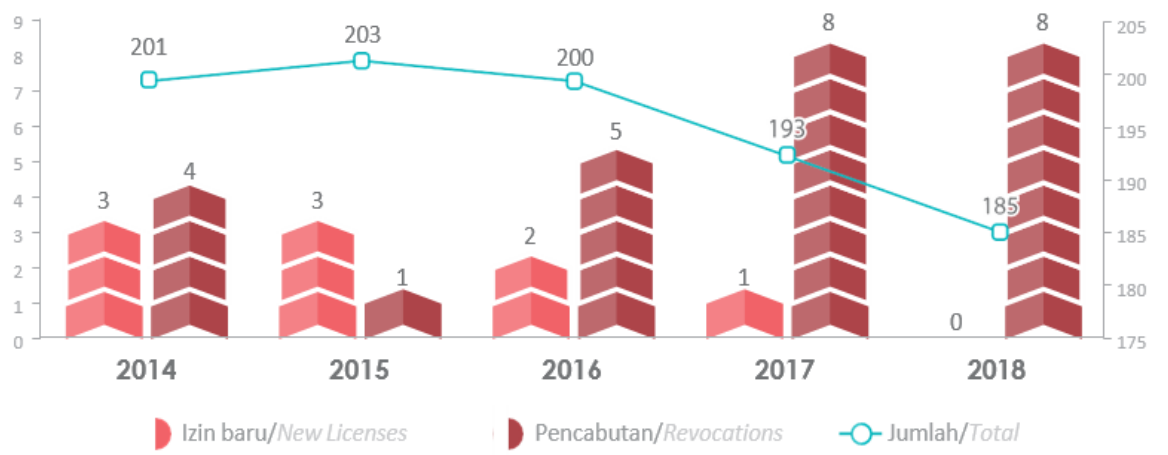

Gambar 1. Jumlah Perusahaan Pembiayaan Tahun 2014-2018 
Berdasarkan Gambar 1. menunjukkan bahwa selama tahun 2014-2018 jumlah perusahaan pembiayaan yang terdaftar di OJK cenderung mengalami penurunan, bahkan dalam 3 tahun terakhir terlihat bahwa jumlah perizinan perusahaan pembiayaan baru mengalami penurunan secara signifikan dibandingkan dengan tahun sebelumnya. Hal ini disebabkan oleh semakin meningkatnya jumlah pencabutan izin usaha serta semakin ketatnya persyaratan. Pencabutan izin usaha tersebut disebabkan oleh beberapa faktor, salah satunya tingkat kesehatan keuangan yang menurun serta belum mampunya perusahaan dalam memenuhi ketentuan bisnis perusahaan pembiayaan sesuai peraturan OJK (POJK). Dalam peraturan tersebut disebutkan bahwa perusahaan pembiayaan yang tidak dapat memenuhi ketentuan permodalan maka izin usahanya akan dicabut.

Secara umum masalah utama yang sering dihadapi perusahaan pembiayaan adalah bagaimana perusahaan tersebut memperoleh dana dan mampu mengelolah dana yang dimiliki secara efektif dan efisien. Kemampuan manajemen dalam menetapkan kebijakan dalam merencanakan, mendapatkan, serta memanfaatkan dana tersebut secara maksimum mampu meningkatkan nilai-nilai perusahaan (Gunawan dan Wahyuni, 2013). Dana yang digunakan dengan baik untuk kegiatan operasional perusahaan tentunya sebagai salah satu alat dalam mencapai tujuan perusahaan, yaitu memperoleh laba.

Selain itu seiring dengan perkembangan ekonomi dunia, perusahaanperusahaan semakin terdorong untuk meningkatkan daya saing. Suatu perusahaan dapat dikatakan mencapai kesuksesan dan berhasil memenangkan persaingan dengan perusahaan-perusahaan lain, salah satu indikatornya yaitu bisa menghasilakan laba bagi pemiliknya (Gunawan dan Wahyuni, 2013). Laba merupakan selisih positif antara pendapatan yang terealisasi dengan beban yang digunakan untuk merealisasikan pendapatan tersebut. Laba yang tinggi mengindikasikan bahwa perusahaan memiliki tingkat kinerja yang baik.

Kinerja perusahaan dapat dinilai melalui laporan keuangan yang disajikan secara teratur pada setiap periode. Informasi tentang posisi keuangan perusahaan, aliran kas perusahaan, laba/rugi perusahaan dan informasi lain yang berkaitan dengan laporan keuangan perusahaan dapat diperoleh dengan melakukan analisis laporan keuangan. Analisis laporan keuangan ini juga dapat dijadikan sebagai salah satu 
pengendalian internal serta sebagai sumber informasi dalam pengambilan keputusan, baik bagi pengguna eksternal maupun internal. Secara umum model analisis keuangan yang sering digunakan adalah analisis rasio keuangan. Analisis rasio keuangan membutuhkan data-data laporan keuangan berupa laporan posisi keuangan dan laporan laba rugi.

Rasio keuangan merupakan indeks yang menghubungkan dua angka akuntansi yang didapat dengan membagi suatu angka dengan angka lainnya (Horne dan Wachowiicz, 2017). Dalam penelitian ini akan digunakan beberapa jenis rasio keuangan yang dianggap memiliki pengaruh penting dalam menentukan kondisi keuangan perusahaan pembiayaan, yaitu; rasio likuiditas yang difokuskan pada Current Ratio (CL), rasio solvabilitas dihitung menggunakan Debt to Assets Ratio (DAR), serta rasio profitabilitas yang meliputi Return On Assets (ROA) dan Return On Equity (ROE).

Beberapa temuan empiris mengenai penelitian ini: Andriyani, (2015) CR dan DAR tidak berpengaruh signifikan terhadap pertumbuhan laba. Sedangkan Puspaningrum et al., (2018) CR dan DAR berpengaruh signifikan terhadap pertumbuhan laba. Heikal et al., (2014) ROE dan ROA berpengaruh signifikan terhadap pertumbuhan laba. Sedangkan Safitri, (2016) ROE tidak berpengaruh signifikan terhadap pertumbuhan laba. Demikian hasil penelitian Pattiasina et al. (2018) ROA tidak berpengaruh signifikan terhadap pertumbuhan laba. Ketidak konsistennya penelitian tersebut sehingga penelitian ini bertujuan untuk mengetahui secara parsial dan simultan rasio keuangan (current ratio, debt to asset, return on asset, dan return on equity) berpengaruh terhadap pertumbuhan laba pada perusahaan sektor pembiayaan yang terdaftar di BEI Tahun 2014-2018.

\section{LANDASAN TEORI}

\section{Teori Sinyal (Signalling Theory)}

Menurut Zulkifli, (2018) teori sinyal menjelaskan mengapa suatu perusahaan memiliki dorongan untuk memberikan informasi mengenai laporan keuangan kepada pihak eksternal. Keterkaitan penelitian ini dengan teori sinyal yaitu terletak pada rasio keuangan, yang merupakan indikator mikro ekonomi, yang mana akan menjadi sinyal dan diprediksi berpengaruh terhadap pertumbuhan laba sehingga rasio keuangan dapat 
dijadikan sebagai acuhan dalam menilai kinerja suatu perusahaan.

\section{Rasio Keuangan}

Menurut Harahap, (2015) rasio keuangan merupakan angka yang didapat dari hasil perbandingan antara satu pos laporan keuangan dengan pos lainnya yang mempunyai hubungan relevan dan signifikan. Berikut rasio keuangan yang berkaitan langsung dengan penelitian ini antara lain:

\section{Current Ratio}

Current ratio digunakan untuk mengukur kemampuan perusahaan dalam memenuhi liabilitas jangka pendek dengan menggunakan aset lancar (Horne dan Wachowiicz, 2017). Tingginya nilai current ratio menggambarkan bahwa perusahaan dalam kondisi likuid. Semakin tinggi nilai rasio ini menunjukkan adanya aktiva lancar yang tidak digunakan secara produktif sehingga akan berpengaruh buruk terhadap profitabilitas perusahaan (Gunawan dan Wahyuni, 2013). Rumus untuk menghitung current ratio adalah sebagai berikut:

$$
\text { Current Ratio }=\frac{\text { Aktiva Lancar }}{\text { Hutang Lancar }}
$$

\section{Debt To Asset Ratio}

Debt to asset ratio digunakan untuk mengukur besarnya aktiva yang dibiayai oleh hutang (Puspaningrum et al., 2018). Rasio ini menekankan pada peran penting pendanaan hutang dalam struktur modal. Penggunaan hutang ini akan meningkatkan nilai profitabilitas, akan tetapi juga meningkatkan risiko. Rumus untuk menghitung DAR adalah sebagai berikut:

$$
D A R=\frac{\text { Total Utang }}{\text { Total Aktiva }}
$$

\section{Return On Asset}

Return on asset digunakan untuk mengukur kemampuan perusahaan dalam menghasilkan laba dari total aktiva yang digunakan (Puspaningrum et al., 2018). Rasio ini menggambarkan sejauh mana perusahaan memperoleh profitabilitas dan manajerial efisiensi secara keseluruhan. Rasio yang tinggi menunjukkan efisiensi dan efektivitas pengelolahan aset perusahaaan yang semakin baik (Hanafi, 2016). Rumus untuk menghitung ROA adalah sebagai berikut: 


$$
R O A=\frac{\text { Laba Bersih }}{\text { Total Aset }}
$$

\section{Return On Equity}

Return on equity digunakan untuk mengukur kemampuan perusahaan dalam menghasilkan laba atas dana yang ditanamkan para pemodal dan pemilik perusahaan. Semakin tinggi nilai rasio ini, semakin besar pula tingkat pengembalian dana yang diberikan kepada pemegang saham (Safitri \& Mukaram, 2018). Rumus untuk menghitung ROA adalah sebagai berikut:

$$
R O E=\frac{\text { Laba Bersih }}{\text { Modal Saham }}
$$

\section{Pertumbuhan Laba}

Menurut Pattiasina et al., (2018) laba adalah peningkatan manfaat ekonomi pada satu siklus akuntansi dalam bentuk kenaikkan aset atau penurunan liabilitas yang berdampak pada peningkatan ekuitas yang bukan berasal dari kontribusi modal. Secara umum pertumbuhan laba dapat diartikan sebagai kenaikan laba atau penurunan laba per saham (Andriyani, 2015).

$$
\text { Pertumbuhan Laba }=\frac{Y_{t}-Y_{t-1}}{Y_{t-1}}
$$

\section{Kerangka Konseptual}

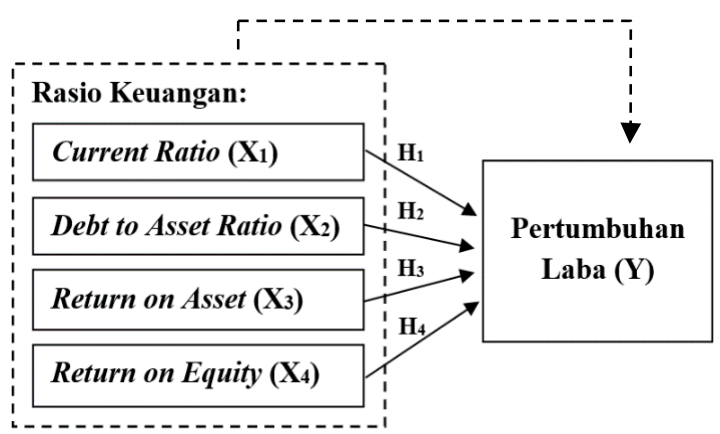

Gambar 2. Kerangka Konseptual

\section{Hipotesis Penelitian}

1. Apakah Current Ratio mempengaruhi Pertumbuhan Laba?

2. Apakah Debt to Asset Ratio mempengaruhi Pertumbuhan Laba?

3. Apakah Return on Asset mempengaruhi Pertumbuhan Laba?

4. Apakah Return on Equity mempengaruhi Pertumbuhan Laba?

5. Apakah Current Ratio, Debt to Asset Ratio, Return on Asset, dan Return on Equity secara simultan dapat mempengaruhi Pertumbuhan Laba? 


\section{METODE PENELITIAN}

Pendekatan penelitian dalam penelitian ini merupakan pendekatan kuantitatif dengan populasi 19 perusahaan sektor pembiayaan yang terdaftar di BEI selama tahun 2014-2018. Metode teknik sampling dalam penelitian ini yaitu menggunakan purposive sampling, sebagai berikut:

Tabel 1. Pengambilan Sampel

\begin{tabular}{|l|c|}
\hline \multicolumn{1}{|c|}{ Kriteria } & Jumlah \\
\hline $\begin{array}{l}\text { Jumlah perusahaan sektor pembiayaan yang terdaftar di Bursa Efek } \\
\text { Indonesia. }\end{array}$ & 19 \\
\hline $\begin{array}{l}\text { Perusahaan sektor pembiayaan yang terdaftar di Bursa Efek } \\
\text { Indonesia periode 2014-2018. }\end{array}$ & 15 \\
\hline $\begin{array}{l}\text { Perusahaan yang melakukan Initial Public Offering (IPO) di atas } \\
\text { tahun 2013. }\end{array}$ & $(2)$ \\
\hline $\begin{array}{l}\text { Perusahaan yang tidak menerbitkan laporan keuangan secara } \\
\text { lengkap selama rentang waktu penelitian yaitu 2014-2018. }\end{array}$ & $(1)$ \\
\hline Perusahaan yang selama proses penelitian mengalami kerugian. & $(2)$ \\
\hline Jumlah & $\mathbf{1 0}$ \\
\hline Jumlah sampel selama 5 tahun (10×5) & 50 \\
\hline Sumber: data diolah (2020) & \\
\hline
\end{tabular}

Data sekunder yang digunakan berupa laporan keuangan yang diunduh melalui alamat situs resmi BEI, yaitu www.idx.co.id. Teknik analisis data menggunakan regresi linear berganda, dengan rumus regresi penelitian ini adalah sebagai berikut:

$$
\mathrm{Y}=\alpha+\beta_{1} \mathrm{X}_{1}+\beta_{2} \mathrm{X}_{2}+\beta_{3} \mathrm{X}_{3}+\beta_{4} \mathrm{X}_{4}+\mathrm{e}
$$

\footnotetext{
Keterangan:

$\mathrm{Y}=$ Pertumbuhan Laba

$\alpha=$ Konstanta

$\beta_{1-4}=$ Koefisien Regresi

$\mathrm{X}_{1-4}=$ Variabel Independen
}

\section{PEMBAHASAN}

\section{Analisis Regresi Linier Berganda}

Berdasarkan data nilai variabel yang diperoleh kemudian diolah menggunakan program SPSS untuk mengetahui persamaan pengaruh antara variabel bebas dan variabel terikat. Berikut hasil output regresi yang disajikan pada Tabel 2. 
Tabel 2. Hasil Regresi Linear Berganda

\begin{tabular}{|c|c|c|c|c|c|}
\hline \multicolumn{6}{|c|}{ Coefficients $^{\mathrm{a}}$} \\
\hline \multirow[b]{2}{*}{ Model } & \multicolumn{2}{|c|}{$\begin{array}{l}\text { Unstandardized } \\
\text { Coefficients }\end{array}$} & \multirow[b]{2}{*}{ Beta } & \multirow[b]{2}{*}{$\mathrm{t}$} & \multirow[b]{2}{*}{ Sig. } \\
\hline & B & $\begin{array}{l}\text { Std. } \\
\text { Error }\end{array}$ & & & \\
\hline $1 \quad$ (Constant) & $-2,991$ & ,671 & & $-4,457$ &, 000 \\
\hline Current Ratio &, 022 &, 003 & ,802 & 7,274 &, 000 \\
\hline Debt To Asset & 3,870 & 1,020 & 572 & 3,793 & ,000 \\
\hline Return On Asset & 347, & ,114 & ,535 & 3,041 & ,004 \\
\hline Return On Equity &,- 068 &, 045 &,- 229 & $-1,500$ & ,141 \\
\hline
\end{tabular}

Berdasarkan Tabel 2. Maka diperoleh persamaan regresi linear berganda adalah sebagai berikut:

$$
Y=-2.991+0.022 X_{1}+3.870 X_{2}+0.347 X_{3}-0.068 X_{4}
$$

Hal ini menunjukkan bahwa secara parsial dari empat variabel independen tersebut hanya variabel ROE yang tidak berpengaruh signifikan terhadap pertumbuhan laba karena nilai signifikansi variabel ROE sebesar 0,141. Nilai tersebut lebih besar daripada toleransi yang digunakan yaitu 0,05 . Sedangkan variabel CR, DAR, dan ROA secara parsial signifikan berpengaruh positif terhadap pertumbuhan laba karena masing-masing nilai signifikansi masing-masing variabel kurang dari 0,05.

Tabel 3. Uji Statistik F

\begin{tabular}{|c|c|c|c|c|c|}
\hline \multicolumn{6}{|c|}{ ANOVA $^{\mathrm{a}}$} \\
\hline Model & $\begin{array}{l}\text { Sum of } \\
\text { Squares }\end{array}$ & Df & $\begin{array}{l}\text { Mean } \\
\text { Square }\end{array}$ & $\mathrm{F}$ & Sig. \\
\hline 1 Regression & 134.266 & 4 & 33.567 & 25.123 & $.000^{\mathrm{b}}$ \\
\hline Residual & 60.124 & 45 & 1.336 & & \\
\hline Total & 194.390 & 49 & & & \\
\hline \multicolumn{6}{|c|}{ a. Dependent Variable: Pertumbuhan Laba } \\
\hline \multicolumn{6}{|c|}{ b. Predictors: (Constant), Return On Equity, Current Ratio, Debt To Asset } \\
\hline
\end{tabular}

Berdasarkan tabel 3, nilai $F_{\text {hitung }}$ sebesar 25.123 dan $F_{\text {tabel }}$ sebesar 2.579. Hal ini menunjukkan bahwa $F_{\text {hitung }}$ lebih besar dari $F_{\text {tabel }}$ yaitu $25.123>2.579$ dengan p-value (sig) $0.000<0.05$ maka $\mathrm{H}_{0}$ ditolak dan $\mathrm{H}_{5}$ diterima. Sehingga dapat disimpulkan bahwa 
rasio keuangan (current ratio, debt to asset, return on asset dan return on equity) secara simultan berpengaruh signifikan terhadap pertumbuhan laba.

Tabel 4. Uji Koefisien Determinasi

\begin{tabular}{|l|c|r|r|c|}
\hline \multicolumn{5}{|c|}{ Model Summary $^{\text {b }}$} \\
\hline Model & $\mathrm{R}$ & R Square & $\begin{array}{c}\text { Adjusted R } \\
\text { Square }\end{array}$ & $\begin{array}{c}\text { Std. Error of the } \\
\text { Estimate }\end{array}$ \\
\hline 1 & $\begin{array}{r}.831 \\
\text { a }\end{array}$ & .691 & .663 & 1.15590 \\
\hline
\end{tabular}

Berdasarkan tabel 4. diperoleh nilai koefisien determinasi sebesar 0.663 atau $66.3 \%$. Hal ini menunjukkan bahwa pengaruh rasio keuangan (current ratio, debt to asset, return on asset, dan return on equity) terhadap pertumbuhan laba sebesar $66.3 \%$, sedangkan sisanya sebesar $33.7 \%$ dipengaruhi oleh faktor lain di luar penelitian ini.

\section{Pengaruh Current Ratio Terhadap Pertumbuhan Laba}

Hasil penelitian menyatakan bahwa current ratio memiliki pengaruh positif dan signifikan terhadap pertumbuhan laba, yaitu semakin tinggi rasio lancar akan semakin tinggi pertumbuhan laba perusahaan. Hal ini terjadi karena adanya anggapan bahwa semakin tinggi nilai rasio lancar maka posisi pemberi pinjaman semakin baik. Dari sudut pandang kreditur nilai rasio yang tinggi mampu memberikan perlindungan apabila terjadi likuidasi perusahaan.

Berdasarkan perspektif teori sinyal, informasi mengenai current ratio akan berpengaruh terhadap keputusan pemberian modal tambahan dari pihak ketiga. Tambahan modal tersebut dapat digunakan untuk membantu meningkatkan aktivitas operasional perusahaan sehingga nilai pertumbuhan laba yang ingin dicapai akan terwujud.

Hasil penelitian ini sejalan dengan penelitian Puspaningrum et al., (2018) dan Pattiasina et al., (2018), yang menyatakan bahwa current ratio berpengaruh positif dan signifikan terhadap pertumbuhan laba. 


\section{Pengaruh Debt To Asset Ratio Terhadap Pertumbuhan Laba}

Debt to asset ratio memiliki pengaruh positif dan signifikan terhadap pertumbuhan laba. Debt to asset ratio menekankan pada pentingnya peran pendanaan hutang jangka panjang dalam struktur modal.

Perusahaan yang memiliki total hutang lebih besar dari total asetnya dapat dikatakan sebagai perusahaan yang tidak solvabel. Perusahaan yang tidak solvabel tentunya memiliki risiko kerugian yang lebih tinggi. Akan tetapi peran pendanaan bagi perusahaan juga sangat penting sehingga perusahaan yang memiliki dana operasional yang tinggi juga berkesempatan untuk memperoleh laba yang tinggi. Jika penjualan tinggi, maka perusahaan bisa memperoleh keuntungan yang tinggi (karena hanya membayar bunga yang sifatnya tetap). Sebaliknya, jika penjualan turun, perusahaan terpaksa bisa mengalami kerugian, karena adanya beban bunga yang tetap harus dibayar (Hanafi, 2016).

Hasil penelitian ini sejalan dengan penelitian Safitri, (2016) dan Puspaningrum et al., (2018) yang menyatakan bahwa debt to asset ratio berpengaruh positif dan signifikan terhadap pertumbuhan laba.

\section{Pengaruh Return On Asset Terhadap Perumbuhan Laba}

Return on asset signifikan berpengaruh positif terhadap pertumbuhan laba. Jadi hasil penelitian ini sesuai dengan teori yakni semakin tinggi nilai ROA maka semakin tinggi pula pertumbuhan laba perusahaan. Perusahaan yang memiliki nilai rasio ROA yang tinggi menunjukkan bahwa usaha tersebut mengalami peningkatkan penjualan atau pendapatan. Selain itu, tingginya nilai rasio ini juga mencerminkan bahwa perusahaan mampu memanfaatkan aktiva yang dimiliki secara produktif sehingga akan menghasilkan return bagi perusahaan, sehingga secara tidak langsung akan berdampak pada pertumbuhan laba yang positif.

Hasil penelitian ini sejalan dengan penelitian Heikal et al., (2014) dan Puspaningrum et al., (2018) yang menyatakan bahwa return on asset berpengaruh positif dan signifikan terhadap pertumbuhan laba. 


\section{Pengaruh Return On Equity Terhadap Pertumbuhan laba}

Return on equity memiliki pengaruh negatif dan tidak signifikan terhadap pertumbuhan laba. Hasil penelitian ini bertentangan dengan teori. Hal ini terjadi karena semakin tinggi nilai ROE maka semakin besar pula jumlah deviden yang dialokasikan ke pemegang saham, laba yang dihasilkan oleh ekuitas ini digunakan untuk menutupi hutang atau dana investasi kepeda investor maupun para pemegang saham. Sehingga perusahaan sektor pembiayaan yang memiliki nilai rasio yang tinggi, cenderung tidak memiliki pertumbuhan laba yang maksimal. Selain itu, kesalahan dalam menentukan kebijakan investasi juga menjadi salah satu alasan mengapa ROE tidak berpengaruh signifikan terhadap pertumbuhan laba.

Hasil penelitian ini sejalan dengan penelitian Safitri, (2016) serta Khaldun \& Muda, (2014) yang menyatakan bahwa return on equity tidak berpengaruh signifikan terhadap pertumbuhan laba.

Pengaruh Rasio Keuangan (Current Ratio, Debt To Asset Ratio, Return On Asset, dan Return On Equity) Terhadap Pertumbuhan laba

Hasil penelitian ini menunjukkan bahwa rasio keuangan (current ratio, debt to asset, return on asset dan return on equity) secara simultan berpengaruh signifikan terhadap pertumbuhan laba. Secara umum analisis rasio keuangan dapat digunakan dalam menilai kinerja keuangan suatu perusahaan. Kinerja keuangan ini sangat erat kaitanya dengan pertumbuhan laba. Hal tersebut sesuai dengan teori yang diungkapkan Safitri, (2016) yang menyatakan bahwa rasio keuangan adalah alat yang digunakan untuk memprediksi pertumbuhan laba. Rasio keuangan dapat digunakan sebagai pedoman dalam mengevaluasi keputusan yang akan diambil untuk kelangsungan hidup perusahaan.

Penelitian Heikal et al., (2014) menyatakan bahwa current ratio, return on asset, dan return on equity secara simultan berpengaruh terhadap pertumbuhan laba. Andriyani, (2015) dan Sari et al., (2017) juga menyatakan demikian current ratio, return on asset dan debt to asset secara simultan berpengaruh signifikan terhadap pertumbuhan laba. 


\section{SIMPULAN DAN SARAN}

\section{Simpulan}

Berdasarkan hasil analisis pada penelitian ini, maka dapat disimpulkan bahwa:

1. Secara parsial current ratio, debt to asset ratio, dan return on asset berpengaruh positif dan signifikan terhadap pertumbuhan laba, sedangan return on equity berpengaruh negatif dan tidak signifikan terhadap pertumbuhan laba pada perusahaan pembiayaan yang terdaftar di BEI tahun 2014-2018.

2. Secara simultan rasio keuangan (current ratio, debt to asset ratio, return on asset, dan return on equity) berpengaruh signifikan terhadap pertumbuhan laba pada perusahaan pembiayaan yang terdaftar di BEI tahun 20114-2018.

\section{Saran}

Penelitian selanjutnya, disarankan untuk melakukan penelitian lanjutan dengan membandingkan perusahaan pembiayaan syariah. Hal ini untuk mengetahui lebih dalam lagi terkait bagaimana perbandingan kinerja keuangan terhadap pertumbuha laba pada perusahaan pembiayaan konvensional dan perusahaan pembiayaan syariah di Indonesia.

\section{DAFTAR PUSTAKA}

Andriyani, Ima. 2015. "Pengaruh Rasio Keuangan Terhadap Pertumbuhan Laba pada Perusahaan Pertambangan yang Terdaftar di Bursa Efek Indonesia." Jurnal Manajemen dan Bisnis 13 (3): 343-58.

Gunawan, Ade, dan Sri Fitri Wahyuni. 2013. "Pengaruh Rasio Keuangan Terhadap Pertumbuhan Laba pada Perusahaan Perdagangan di Indonesia." Jurnal Manajemen \& Bisnis 13 (01): 63-84.

Hanafi, Mamduh M. 2016. Manajemen Keuangan. 2 ed. Yogyakarta: BPFE.

Harahap, Sofyan Syafri. 2015. Analisis Kritis atas Laporan Keuangan. 1 ed. Jakarta: Rajagrafindo Persada.

Heikal, Mohd, Muammar Khaddafi, dan Ainatul Ummah. 2014. "Influence Analysis of Return on Assets ( ROA ), Return on Equity ( ROE ), Net Profit Margin ( NPM ), Debt To Equity Ratio ( DER ), and current ratio ( CR ), Against Corporate Profit Growth In Automotive In Indonesia Stock Exchange." International Journal of Academic Research in Business and Social Sciences 4 (12): 101-14.

Horne, James C. Van, dan John M. Wachowiicz. 2017. Prinsip-Prinsip Manajemen Keuangan. 13 ed. Jakarta: Salemba Empat.

Khaldun, Khalidazia Ibnu, dan Iskandar Muda. 2014. "The Influence of Profitability and Liquidity Ratios On The Growth of Profit of Manufacturing Companies (A 
Study of Food and Beverages Sector Companies Listed On Indonesia Stock Exchange Period 2010-2012 )." International Journal of Economics, Commerce and Management II (12): 1-17.

Nurcahya, Ipak Ayu H. 2018. "7 Juni, 12\% Perusahaan Multifinance Tak Sehat, OJK Klaim Industri Masih Baik,” 2018. https://financial.bisnis.com.

Pattiasina, Victor, Fajar Rina Sejati, Yohanes Cores Seralurin, Ridolof Wenand Batilmurik, dan Mutiara Austin Al Aziz. 2018. "The Impact of Financial Ratios towards Profit Changes." International Research Journal of Management, IT \& Social Sciences 5 (5): 1-16.

Puspaningrum, Regina Christy, Y. Djoko Suseno, dan Untung Sriwidodo. 2018. "Analisis Pengaruh Rasio Keuangan Terhadap Pertumbuhan Laba Perusahaan (Studi Empiris pada Perusahaan Food \& Beverages yang Terdaftar di BEI Tahun 2009-2013).” Junnal Manajemen Sumber Daya Manusia 12 (2): 169-83. Safitri, Anggi Maharani, dan Mukaram. 2018. "Pengaruh ROA , ROE , dan NPM Terhadap Pertumbuhan Laba Pada Perusahaan Sektor Industri Barang Konsumsi Yang Terdaftar di Bursa Efek Indonesia." Jurnal Riset Bisnis dan Investasi 4 (1): 25-39.

Safitri, Isnaniah Laili Khatmi. 2016. "Pengaruh Rasio Keuangan Terhadap Pertumbuhan Laba pada Perusahaan Manufaktur Sektor Industri Konsumsi yang Terdaftar di Bursa Efek Indonesia (Studi Kasus pada Perusahaan Kalbe Farma Tbk Periode 2007-2014)." Jurnal Akuntansi dan Bisnis 2 (2): 137-58.

Sari, Dian Permata, Hadi Paramu, dan Elok Sri Utami. 2017. “Analisis Pengaruh Rasio Keuangan dan Ukuran Aset pada Pertumbuhan Laba Perusahaan Manufaktur yang Terdaftar pada Bursa Efek Indonesia Periode 2010-2013.” eJournal Ekonomi Disnis dan Akuntansi IV (1): 63-66.

Walfajri, Maijal. 2019. "4 Agustus, Kinerja Pembiayaan Multifinance Hanya Tumbuhn 4,29\% Hingga Pertengahan Tahun Ini," 2019. https://m.kontan.co.id.

Yansi, Nur Hari. dan. Tetuko, Bambang. 2015. "Analisis Kinerja Keuangan PT Adira Dinamika Multifinance Tbk dengan Analisis Rasio dan Analisis Du Pont", Jurnal Ilmiah Manajemen dan Bisnis, 1 (3).

Zulkifli. 2018. "Pengaruh Current Ratio, Debt To Equity Ratio dan Net Profit Margin Terhadap Earning Growth pada Perusahaan Pertambangan yang Tercatat di Bursa Efek Indonesia." Jurnal Ekonomi XXIII (02): 175-89.

www.ojk.co.id

www.sahamok.com 